\title{
A CRIANÇA E O VIAJANTE ALEGORIAS DA CORPORALIDADE MODERNA EM WALTER BENJAMIN
}

\section{Priscilla Stuart da SILVA *}

* Mestra em Educação e Doutoranda no Programa de Pós-Graduação em Educação na Linha de Pesquisa em Filosofia da Educação pela Universidade Federal de Santa Catarina, Brasil. E-mail: priscillastuart.di@gmail.com.

Artigo submetido em março/2015 e aceito em agosto/2015

DOI: http://dx.doi.org/10.15628/dialektike.2015.2848

\section{RESUMO}

Este artigo tem como objetivo discutir a noção de uma corporalidade em Walter Benjamin. Pensamos que os ensaios Infância berlinense: 1900 e Diário de Moscou, ao transcenderem os gêneros literários da "autobiografia" e dos

"diários de viagem", conduzem-nos a reflexões que nos mostram o lugar do corpo na formação da subjetividade. Para mostrar como isso sucede, abordamos a figura da criança e do viajante como emblemáticas da modernidade.

\section{PALAVRAS-CHAVE: Criança. Viajante. Corporalidade. Walter Benjamin.}

\section{ABSTRACT}

This article aims to discuss the notion of corporality in Walter Benjamin. For we chose the Berlin Childhood around 1900 and Moscow Diary, for upon transcend the literary genres of the "autobiography" and "travel journals", lead us

to reflections that show the place of the body in the formation of subjectivity. To show how this happens, we approach the figure of the child and traveler as emblematic of modernity.

KEYWORDS: Child. Traveler. Corporeality. Walter Benjamin.

\section{ALEGORIAS DA CORPORALIDADE}

Por detrás dos teus pensamentos e sentimentos, meu irmão, há um senhor mais poderoso, um guia desconhecido. Chama-se Si mesmo. Habita no teu corpo; é o teu corpo. Há mais razão no teu corpo do que na tua melhor sabedoria. E quem sabe para quem necessitará o teu corpo precisamente da tua melhor sabedoria.

Friedrich Nietzsche

Nos ensaios de Benjamin analisados ao longo do presente texto, a saber, Infância berlinense: 1900 e Diário de Moscou, a noção de corpo é transcrita para um plano mais indireto em nossa interpretação: o plano subjetivo, ou seja, naquele em que se dá a formação. Investigando, comparativamente, o corpo do viajante e o corpo da criança em seus 
desdobramentos educativos, chegamos preliminarmente à seguinte ideia: que é pelo corpo que apreendemos os objetos do mundo natural e cultural ao nosso redor, e por essa via conhecemos o mundo subjetivamente. Corpo e subjetividade, sob esse ponto de vista, se confundiriam - embora sem transcender, necessariamente, a separação sujeito-objeto:

O corpo é o peso sentido na experiência [...]. Meu corpo é a materialização daquilo que me é próprio, realidade vivida e que determina minha relação com o mundo. Dotado de uma significação incomparável, ele existe à imagem de meu ser: é ele que eu vivo, possuo e sou, para o melhor e para o pior. Conjunto de tecidos e de órgãos, suporte da vida psíquica, sofrendo também as pressões do social, do institucional, do jurídico, os quais, sem dúvida, pervertem nele seu impulso primeiro. ${ }^{1}$

Especulativamente falando, poderíamos pensar, a partir da filosofia nietzscheana - cujos ecos, certamente, são audíveis nos escritos de Benjamin — que o corpo é a "grande razão humana" ". Se a formação também se realiza pelo corpo, como porta de entrada para o mundo à nossa volta, não à toa ele foi objeto de controle e domínio por mecanismos disciplinares psiquiátricos, sanitários, escolares, legislativos, etc ${ }^{3}$. Os sentidos do corpo revelam nossos limites e possibilidades:

Nossos "sentidos", na significação mais corporal da palavra, a visão, a audição, não somente as ferramentas de registro, são órgãos de conhecimento. Ora, todo o conhecimento está a serviço do vivo, a quem ele permite perseverar no seu ser. ${ }^{4}$

Pensando mais especificamente sobre os sentidos demarcados no universo infantil, encontramos uma correspondência entre o corpo e o mundo na aquisição de experiências. $\mathrm{O}$ olhar $^{5}$ - e isso é levado ao paroxismo na modernidade, de acordo com a interpretação de Benjamin — é o sentido por excelência, o mais importante, pois é com ele que adquirimos,

\footnotetext{
${ }^{1}$ ZUMTHOR, Paul. Performance, recepção, leitura. Tradução de Jerusa Pires Ferreira e Suely Fenerich. São Paulo: Cosac Naify, 2007, p. 23-24.

${ }^{2}$ Cf. Expressão cunhada por Nietzsche: "O corpo é uma grande razão em ponto, uma multiplicidade com um só sentido, uma guerra e uma paz, um rebanho e um pastor". In: NIETZSCHE, Friedrich. Assim falou Zaratustra. São Paulo: Martin Claret, 2009, p. 43.

3 Com todas essas análises relacionadas ao corpo, Foucault realizou uma verdadeira arqueologia da modernidade.

${ }^{4}$ ZUMTHOR, 2007, p. 81.

${ }^{5}$ Cf. "Além do barulho ou dos odores desagradáveis, a experiência sensorial do homem da cidade resume-se essencialmente à da visão. O olhar, sentido da distância, da representação, e até mesmo da vigilância, é o vetor essencial da apropriação pelo homem de seu meio ambiente”. In: BRETON, David Le. Antropologia do corpo e modernidade. Tradução de Fábio dos Santos Creder Lopes. Petrópolis: Vozes, 2011, p. 163-164.
}

Dialektiké. Ano 2, v. 2, out 2015, p. 59-88 | Revista de Filosofia 
sem mediação, a experiência e o conhecimento sobre nós mesmos e o mundo. Conhecemos, reconhecemos, fazemos associações, identificamos semelhanças, apreendemos o mundo e o representamos. Poderíamos pensar aqui em diversas modalidades do sentido da visão para Benjamin, mas não podemos esquecer que, sobremaneira, ele entende o corpo como potência, possibilidade. $\mathrm{O}$ corpo da criança e o corpo do viajante estão abertos à experiência. $\mathrm{O}$ olhar é o sentido-mor na história da filosofia: as descrições, desde Platão, são sempre imagéticas, relacionadas ao conhecimento da verdade, e o olhar sendo sempre o sentido que nos desvelaria essa alétheia ${ }^{6}$.

Na infância, o sentido do olhar está muito marcado pelos processos imaginativos da criança. A visão potencializa a capacidade de projeção de si no outro, uma vez que a identificação do infante não se realiza somente com o que está próximo ou que é seu igual, mas nos objetos inanimados, na natureza, nos animais, nas atividades lúdicas, etc.

O sentido da visão em Infância berlinense é carregado de nostalgia, como podemos constatar em alguns aforismos, como "Panorama Imperial": a visão da "pequena moldura" ou da "cidadezinha de Aix" remete à fronteira, ao limiar da memória entre o passado e a condição humana do presente, um lugar ainda não definido entre esses dois tempos. Talvez esse "entre lugares" seja o da saudade que, com um grande esforço da memória voluntária ${ }^{7}$, recupera a dimensão de uma vida que já não existe mais, ou, pela imaginação, uma vida que anseia por uma existência que ainda não se configurou.

A associação entre o corpo da criança e o do viajante permite elaborar uma definição não casual: o corpo da criança é sempre movimento: da imaginação, da memória, da descoberta, do jogo, no qual tempo e espaço se confundem. Reiteramos essa afirmação levando em consideração o aforismo "Livros para rapazes", em que as letras (dimensão tátil, visual) jogam com a imaginação, momento em que o corpo da criança assemelha-se ao de um viajante que percorre o tempo por meio de sua memória:

Mas agora tinha chegado o momento de seguir no torvelinho das letras as histórias que me tinha fugido à janela. As terras distantes que nelas encontrava envolviam-se, como os flocos, em jogos familiares umas com as

\footnotetext{
${ }^{6}$ Cf. “[...] O olhar é verdadeiramente 'o fundo do homem' - mas esse depósito do humano, essa opacidade abissal, essa miséria do semblante (na qual tantas vezes o amante se perde e que o homem político é capaz de avaliar tão bem, para fazer disso um instrumento de poder), é o único sinal genuíno da espiritualidade". In: AGAMBEM, Giorgio. Ideia da prosa. Tradução de João Barrento. Belo Horizonte: Autêntica, 2012, p. 122.

7 Cf. "A memória voluntária é um fichário que fornece um número de ordem ao objeto, atrás do qual ele desaparece”. In: BENJAMIN, Walter. Imagens do pensamento. Trad. João Barrento. Lisboa: Assírio e Alvim, 2004, [H 5,1].
} 
outras. E como a distância, quando neva, já não nos leva para longe, mas para dentro, Babilônia e Bagdade, Akko e Alasca, Tromsö e o Transvaal estaval todas dentro de mim. ${ }^{8}$

Como podemos perceber nesse trecho, a criança torna-se um viajante quando é conduzida pelas histórias dos livros, onde cada letra é um lugar para percorrer: as páginas viradas, a tinta das letras, a encadernação, etc., são obstáculos, trilhas, rumos que a conduzem aos "tênues fios de uma rede na qual [ela se deixa] enredar" ${ }^{\prime \prime}$.

O livro é um artefato cultural que leva o universo infantil a recriar, em sua imaginação, objetos, de acordo com a história contada, semelhante à imagem de hieróglifos. Em "Visão do livro infantil"10 o autor compara essa reconstrução imagética realizada pela criança aos ideogramas do sistema discursivo chinês, no qual as representações gráficas assemelham-se às formas de pensamento da criança ao visualizar as letras do alfabeto, momento em que elaboram verdadeiros "cenários" com as palavras. "Os caminhos" pelos quais esses livros ou cartilhas infantis conduzem a criança a uma formação pelas formas, pelos hieróglifos, ao grafismo das histórias representadas, “está portanto muito distante da drasticidade embotada que levava a pedagogia racionalista a recomendá-los"11.

As descrições da visão são indissociáveis das do toque, do tato: sentido reconhecidamente predominante nas crianças. A corporalidade da criança aproxima os objetos que estão distantes no tempo pelo simples desejo da vontade e do sonho. Sonho e realidade misturam-se ao seu imaginário. Benjamin, através da percepção infantil, busca “anular” — ou melhor, colocá-las sob nova tensão e hierarquia — as dicotomias entre sujeito e objeto, interioridade e exterioridade, sonho e realidade. Ele busca uma integração do real que se perdeu, busca "salvar" o indivíduo do seu isolamento e da ruína do mundo moderno. Os sentidos da criança preservam e propõem novos usos para esse mundo recente e isolado de sua história.

Essa ideia pode ser encontrada naquilo que Benjamin chama de sentido ou instinto tátil, presente, com força, nos aforismos "Livros para rapazes", “A Febre”, "A meia" e "A caixa de costura". Em todos é possível perceber que a dimensão física dos dedos que tocam mostra uma história que está por trás da materialidade dos objetos, como do livro em sua encadernação, o torvelinho de neve ao cair, o tubo (termômetro) que a mãe manipula, os pares

\footnotetext{
${ }^{8}$ BENJAMIN, 2004, p. 85.

${ }^{9}$ Ibid, p. 85.

${ }^{10}$ BENJAMIN, 2009, p. 69.

${ }^{11}$ Ibid, p. 72.
} 
de meia na cômoda, o dedal da costura. Esse "conhecimento" se dá no/pelo corpo e não na/pela razão cognoscível.

O sentido do toque também precisa ser compreendido pela perspectiva da cultura material. A coleção de caixas e brinquedos infantis que o filósofo encontra na cidade de Moscou também nos aponta a dimensão do tato, pela sua simplicidade e solidez, pela referência a uma espontaneidade dos artefatos culturais, pela marca do trabalho rústico da produção — sem a conhecida mediação lúdica que as indústrias de brinquedo promovem para o mundo infantil -, recorrendo, para isso, ao valor do trabalho artesanal, das mãos do artesão ou artesã, presente nos objetos, ou seja, a "uma relação mais imediata entre madeira e tinta, tanto nos brinquedos mais primitivos quanto nos laqueados mais elaborados"12.

O olfato, sentido mais impositivo e mais incontrolável, não é lembrado pela razão que perscrutou aquele período da sua biografia, mas pela lembrança que fora assimilada pelo corpo, pelos sentidos, pelos sentimentos associados a essas memórias. O olfato, como é possível depreender da leitura do aforismo "Manhã de inverno", está sempre ligado aos sentimentos e aos desejos:

\begin{abstract}
Ainda as persianas não estavam abertas, e já eu trancava pela primeira vez a portinhola do fogão para ver como estava a maçã. Por vezes, ainda mal se alterara o seu aroma. E eu esperava pacientemente até me parecer sentir o cheiro espumoso que vinha de uma célula da manhã de inverno, mais profunda e mais discreta que o cheiro da árvore na noite de Natal. Lá estava o fruto escuro e quente, a maçã que chegava até mim, familiar e apesar disso mudada, como um velho conhecido depois de uma viagem. ${ }^{13}$
\end{abstract}

Similarmente Proust nos transporta para os mesmos sentimentos na descrição dos cheiros de seu passado, vinculados a desejos já abandonados:

O odor, no ar gelado, dos raminhos de árvores era como um pedaço do passado, uma branquisa invisível desprendida de inverno antigo e avançado quarto adentro, estriada, muitas vezes, aliás por um tal perfume, um tal clarão, como em outros anos, nos quais eu me encontrava remergulhado, invadido, antes mesmo de as ter identificado, pela alegria de esperanças há muito abandonadas. ${ }^{14}$

\footnotetext{
12 BENJAMIN, 1989, p. 29.

13 Ibid, p. 87.

${ }^{14}$ PROUST, Marcel. A prisioneira. Trad. de Manuel Bandeira. São Paulo: Globo, 2011, p. 33-34.
} 
Conforme abordado anteriormente, a obra do literato de Combray é de extrema importância para o filósofo berlinense, também no que diz respeito a um saber sensível que a própria biografia conduz. Esses acontecimentos, que são revisitados pela memória que recorda o vivido, fornecem uma imensidão material de uma vida inteira ${ }^{15}$, daí a importância do olfato, como sentido tão revelador.

Certamente os cheiros nos deslocam no tempo mais do que ocorre com qualquer outro dos sentidos; eles nos revelam o pano de fundo de uma lembrança, quando o corpo é exaltado pela "viagem através da terra escura [...] em que tinha absorvido os aromas de todas as coisas que o dia reservava" 16 .

Relacionado aos aromas acima mencionados — mas não apenas com eles —está, inegavelmente, o sentido do paladar. No aforismo "As cores" há um jogo entre dois sentidos na apreciação do pacote de chocolates: o do olhar e do gosto. Em "Manhã de inverno" encontramos o jogo entre o olfato e o paladar. Em "A Febre", esses sentidos aparecem em meio aos delírios da enfermidade, junto a uma imagem construída sob os movimentos proporcionados pela narração de uma estória.

A audição é também um sentido marcante em Infância berlinense, presente, por exemplo, na inserção do telefone no interior das residências burguesas, como vimos anteriormente no comentário sobre o aforismo "Telefone", ou no contar histórias que a natureza narrava em silêncio, como em "Livros para rapazes", ou no barulho do bater dos tapetes, em “A Febre”. Em suma, sons que denotavam hábitos não apenas da criança que Benjamim havia sido mas também comportamentos e costumes associados à vida burguesa.

O som produzido pelas batidas nos tapetes, por exemplo, é um signo que se refere à existência de um nível social que servia à burguesia, responsável pela limpeza e manutenção da casa. Benjamin é muito sutil nesses relatos, mas revela uma cumplicidade (já do adulto Benjamin) com aqueles que vinham substituir a mãe, reconhecendo neles "o verdadeiro adulto que nunca parava, não largava o trabalho, por vezes abrandava e se dispunha a tudo, indolente e amortecido, e outras caía num galope inexplicável, como se lá em baixo todos se apressassem para não apanhar chuva"17.

Em "A lontra", encontramos o corpo na expectativa, no desejo quanto ao futuro proporcionado pela experiência auditiva da chuva. Visualizamos também a distância que

15 BENJAMIN, Walter. A imagem de Proust. In: Paulo Rouanet. São Paulo: Brasiliense, 2010, p. 37.

${ }^{16}$ BENJAMIN, 2004, p. 87.

${ }^{17}$ Ibid, p. 95. 
separa a segurança de um lar burguês do mundo lá fora, a qual é encurtada pela imagem da lontra, animal que, no contexto do aforismo, representa a magia, o sagrado da natureza, essa esfera impenetrável que é, ao mesmo tempo, passível de representação pela imaginação de uma criança, aguçada pelos sentidos da audição:

Pois nunca o dia me era tão gratificante, nem tão longo, como quando a chuva a penteava lentamente, horas e minutos, com os seus dentes finos ou grossos. E ela, obediente como uma menina pequena, inclinava a risca do cabelo debaixo daquele pente cinzento. E eu não me cansava de olhar para ela [a lontra]. Esperava. Não até ela desistir, mas que a chuva engrossasse e caísse mais forte. Ouvia-a tamborilar nas vidraças, correr pelas goteiras cheias e descer gorgolejando para os esgotos. Aquela boa chuva dava-me a sensação de segurança. E o meu futuro sussurrava-me isso ao ouvido, como se canta uma canção de embalar junto ao berço. Entendia muito bem como se cresce na chuva. ${ }^{18}$

O sentido auditivo também é objeto de dominação, de treinamento por meio de um aparato técnico, como no caso do aforismo "Telefone". Mas não é apenas o ouvido, senão os sentidos como um todo, o corpo inteiro, que são objetos de uma educação nesse período histórico, na formatação adquirida de uma postura, o tom de voz, os modos de comportamento de uma sociedade burguesa. Conforme Costa, a educação desse corpo de classe exigiu a submissão a

rigorosas disciplinas, entre as quais as sexuais, as intelectuais, as higiênicas e a apresentação social. As disciplinas sexuais visavam moderar os prazeres sensuais, de modo a drená-los para o sentimentalismo amoroso, o cuidado com a família ou a sublimação artístico-científica. As intelectuais buscavam adequar os sentidos e a motricidade às exigências da cultura erudita: ler em voz baixa e de forma correta, escrever bem, portar os livros em posição corporal conveniente etc. As higiênicas tinham por objetivo adestrar a visão, a audição, o tato, o gosto e o olfato de modo a despertar nos indivíduos desprezo ou repulsa pela sujeira, feiura e grosseria dos corpos mal-educados. Normas de limpeza; maneiras de mesa; ritmos de trabalho, sono e lazer; apreciação de certos esportes, etc. eram itens obrigatórios na educação das crianças burguesas nas casas ou nas escolas. Por fim, as disciplinas de apresentação social ou regras de etiqueta ensinavam os indivíduos como se vestir, andar, sorrir, sentar, receber convidados, conversar, dançar, cantar, tocar instrumentos musicais, etc., a fim de que o 'berço' dos 'bem-nascidos' fosse evidente à primeira vista. ${ }^{19}$

Um exemplo dessa disciplina encontramos no aforismo "Escrivaninha". Nele se encontra um exemplo da criação e formação de uma criança burguesa, à qual foi submetido o próprio

\footnotetext{
${ }^{18}$ Ibid, p. 97.

${ }^{19}$ COSTA, Jurandir F. Notas sobre a cultura somática. In: moral do espetáculo. Rio de Janeiro: Garamond, 2005, p. 206-207. . O vestígio e a aura: corpo e consumismo na
} 
filósofo durante toda sua educação formal. Esse objeto, espécie de carteira escolar encontrada no interior da casa paterna, havia sido prescrito por um médico para o Benjamin criança. E apesar de ser fruto de duas disciplinas, a higiênica e a intelectual, a escrivaninha também abrigava um mundo à parte em seu interior: o mundo das letras, da disciplina intelectual, mas não apenas isso.

Podemos perceber uma série de elementos, como a imaginação que ganha liberdade de espaço, de tempo; os cadernos usados livres da opressão dos deveres obrigatórios que recebem novos significados; momento da criação de histórias ensaiadas, improvisadas no universo particular da criança, tempo da experiência, do cultivo e apreciação demorados dos objetos, ou seja, tempo subjetivo da criação infantil:

Essa escrivaninha junto à janela logo se tornou meu recanto favorito. Frequentemente, ao voltar da escola, a primeira coisa que eu fazia era festejar meu reencontro com a escrivaninha, ao mesmo tempo em que já a transformava no palco de uma de minhas ocupações prediletas - a decalcomania, por exemplo. Num instante, no lugar antes tomado pelo tinteiro, surgia uma xícara de água morna, e eu começava a recortar as figuras. Quanto me prometia o véu através do qual me fitavam das folhas dobradas e dos cadernos! Embora, afinal, eu me fartasse também daquele passatempo, era assim que sempre encontrava um pretexto de adiar os deveres de casa. Era com prazer que revia os velhos cadernos, dotados agora de um valor especial, que era o de eu tê-los resgatado do domínio do professor, que teria direito sobre eles. Agora deixava o olhar recair sobre as correções ali registradas em tinta vermelha, e um prazer sereno me tomava. Pois, assim como os nomes dos mortos gravados nas sepulturas já não podem ser úteis ou prejudiciais, ali estavam notas que haviam entregado todo seu poder a outras mais antigas. Com o espirito e a consciência mais tranquila eu podia perder horas na escrivaninha tratando dos cadernos e dos livros escolares. (...) Assim, aquela escrivaninha guardava, sem dúvida, certa semelhança ao banco escolar, mas sua vantagem era que nela eu ficava protegido e dispunha de espaço para esconder coisas de que ele não deveria saber. ${ }^{20}$

Em “A febre”, outro aforismo que remete à imaginação e à criação, narra-se as histórias que o pequeno Benjamin ouvia em seu leito, quando estava doente, as quais “[...] permitiam um reavivamento, uma retomada da tradição e, nesse sentido, um duplo sentimento: de conforto e resignação em relação ao futuro conjeturado/prometido" ${ }^{21}$. Conforto porque a narrativa, por um lado, aproximava a criança de sua história familiar - "evocava-se a carreira de um

${ }^{20}$ BENJAMIN, 2009, p. 119-120.

${ }^{21}$ MOMM, Caroline M. Entre memória e história: estudos sobre a infância em Walter Benjamin. 2006.116 f. Dissertação (Mestrado) - Universidade Federal de Santa Catarina, Centro de Ciências da Educação. Programa de Pós-Graduação em Educação, Florianópolis, 2006, p. 96. 
antepassado remoto, as regras de vida do avô, como se quisessem fazer ver que seria precipitado abdicar, por uma morte prematura, dos grandes trunfos que a minha linhagem me punha na mão"22 — e, por outro, distanciava-a da convalescença: "a dor era um dique que só a princípio resistia à narrativa; mais tarde, quando esta ficava mais forte, era engolida pelo abismo do esquecimento" 23 .

A dor, dimensão irrenunciável de nossa corporalidade, é tema frequente em Infância berlinense. Nesse mesmo aforismo, "A febre", ela aparece como embriaguez causada pela convalescença e também associada à narrativa e ao aspecto sensorial do toque ${ }^{24}$. Na mesma medida, Benjamin relaciona a dor com o esquecimento, com o prazer ${ }^{25}$, com a imaginação e, por consequência, com a cura. Ela também parece ter uma função "educativa", na medida em que ensina a ser paciente, a respeitar o ritmo do corpo, educando os sentidos ao tempo da espera. O silêncio, fundamental para a pronta e completa recuperação da enfermidade, também é educador do anseio, pois permite o encontro da serenidade. O silêncio é um elemento relevante como pré-condição do discurso: o ato de narrar uma história prevê o silêncio como condição do ouvir e como elemento da imaginação, uma vez que até o torvelinho da neve conseguia contar "histórias em silêncio" para o Benjamin criança ${ }^{26}$.

Pensamos que a dor e o prazer corporal convertem-se em conhecimento de si mesmo. Por meio deles, conhecemo-nos como sujeitos encarnados. São fontes de entendimento de nossos órgãos internos, de nossas sensações que, em última instância, fornecem uma representação muito fidedigna de nós mesmos ${ }^{27}$.

A resignação em relação ao futuro causada pelas histórias contadas pela mãe, da qual nos fala Momm, deixa-se entrever com maior clareza em outro aforismo, "Manhã de

\footnotetext{
22 Ibid, p. 93-94.

${ }^{23}$ Ibid, p. 93.

${ }^{24} \mathrm{Cf}$. Benjamin discorre de modo semelhante no aforismo "Conto e cura", presente em Imagens do pensamento: “[...] Não constituirá a narração o clima adequado e a condição mais favorável de tanta cura? E ainda: não seria toda doença curável se se deixasse arrastar o mais longe possível - até a foz - pela corrente da narração? Se imaginarmos que a dor é um dique que resiste à corrente da narrativa, constataremos claramente que ele será derrubado se a inclinação for suficientemente forte para arrastar para o mar do esquecimento feliz tudo o que encontrar pelo caminho. A mão que acaricia traça o leito desse rio”. In: BENJAMIN, 2004, p. 250.

${ }^{25}$ A dor e prazer são dimensões de uma mesma realidade. Já os antigos reconheciam essas fronteiras tênues entre um e outro: “A dor do corpo não é de duração contínua, mas a dor aguda dura pouco tempo, e aquilo que apenas supera o prazer da carne não permanece nela muitos dias. E as grandes enfermidades têm, para o corpo, mais abundante o prazer do que a dor”. In: EPICURO. Da natureza. In: EPICURO et al. Os pensadores. São Paulo: Abril Cultura, 1985.

${ }^{26}$ BENJAMIN, 2004, p. 85.

${ }^{27} \mathrm{Cf}$. "A doença é um emblema social, tal como a loucura entre os Antigos. Os doentes têm um conhecimento muito especial do estado da sociedade. Neles, que não têm papas na língua, manifesta-se um faro infalível para detectar a atmosfera em que respiram os seus contemporâneos”. In: BENJAMIN, 2004, p. 252.
} 
inverno", em que Benjamin, ao recordar do peso da obrigação de ir para a escola e dos constrangimentos a que lá era submetido, em contraste com o cuidado e a proteção que recebia em casa, afirma:

Mas uma vez chegado [na escola], o simples toque da carteira fazia regressar, dez vezes maior, todo o cansaço que antes parecia ter-se dissipado. E com ele aquele desejo: poder dormir à vontade. Devo tê-lo pedido um milhar de vezes, e mais tarde realizou-se de facto. Mas muito tempo haveria ainda de passar antes de eu perceber que, sempre que tive esperança de conseguir uma situação e um ganha pão estáveis, essa esperança foi vã. ${ }^{28}$

Vinculadas à dor e ao prazer encontram-se as temáticas da morte e da sexualidade, presentes com força em Infância berlinense $e^{29}$. Em “A Febre”, a morte é representada pela doença, pela iminência do agravamento do estado de saúde de uma criança que sempre é acometida pela convalescença. Uma criança que parece frágil, fraca, mas com uma imaginação intensa, que consegue criar, por exemplo, histórias num jogo de luzes e sombras na parede do quarto. Podemos lembrar ainda das lições que a resignação, a virtude da paciência, lhe fornece na vida adulta, conforme narrado pelo autor no aforismo.

"Notícia de uma morte" é outro desse conjunto de fragmentos em que a morte encontra lugar de destaque. Chama a atenção, considerando os propósitos deste trabalho, que Benjamin tenha fixado com mais intensidade - a propósito da notícia do falecimento de um parente distante, trazida por seu pai - a lembrança de seu quarto, em sua dimensão espacial: “[...] naquela noite, fixei na memória meu quarto e minha cama, do mesmo modo como alguém grava com mais precisão um lugar, sentindo que deverá voltar a ele algum dia a fim de buscar algo esquecido". Tratava-se de um lugar seguro, o quarto de uma criança inocente, que não conhecia ainda as desventuras da vida, mas que havia sido, pela primeira vez, apesar da relutância e proteção paterna, "assombrado" pela finitude da vida. Nesse aforismo também percebemos que a morte constituía um tema quase proibido, dimensão humana que deveria ser esquecida, velada, convertendo-se em um tabu social. Destarte, em suas lembranças pessoais, Benjamin revela um aspecto não somente fisiológico do interior da vida burguesa, mas também sociológico.

\footnotetext{
${ }^{28} \mathrm{O}$ grifo é nosso.

${ }^{29}$ O tema da relação entre morte e sexualidade fora objeto de reflexão de importantes trabalhos sobre esse texto memorialístico de Benjamin, como o de Momm (2006) e, sobretudo, o de CHAVES, Ernani. Sexo e morte na Infância Berlinense, de Walter Benjamin In: SELIGMANN-SILVA, M. Leituras de Walter Benjamin. São Paulo: Annablume, 1999. p. 127-146.
}

Dialektiké. Ano 2, v. 2, out 2015, p. 59-88 | Revista de Filosofia 
Em "Blumeshof 12", a morte, assim como a miséria, contrastava com o "sentimento imemorial de segurança burguesa que irradiava" ${ }^{30}$ da casa da avó materna, anciã e viajante ${ }^{31}$, localizada no endereço que dá nome ao aforismo, sobretudo por conta dos ornamentos e do mobiliário, feitos para “durar para sempre”, típicos de toda uma época e geração:

O recheio de seus muitos quartos [da casa da avó] não honraria hoje nem um ferro-velho. É que, embora os produtos dos anos setenta [1870] fossem muito mais sólidos do que os que vieram depois com a Arte Nova, o seu toque inconfundível estava na complacência com que abandonavam as coisas ao correr do tempo e, quanto ao futuro, no modo como apenas confiavam na resistência do material e nunca em princípios de funcionalidade. Aqui, dominava um tipo de móveis que, devido à persistência com que acumulavam ornamentos de muitos séculos, respiravam confiança e durabilidade. ${ }^{32}$

No interior dessas residências "a morte não estava prevista" 33 , por isso, diz Benjamin, seus moradores eram conduzidos para morrer em outro lugar, como os sanatórios, deixando uma imagem duradoura de aconchego naquelas casas, mas que, no entanto, não podia ser sustentada sem fraturas: “[...] pareciam tão confortáveis de dia, e à noite transformavam-se em cenário de maus sonhos. [...] tais sonhos eram o preço que eu tinha de pagar pelo aconchego" 34 . Esse tema também aparece em outros textos de Benjamin, como em "Paris do segundo império", no qual esse apego burguês pelas residências e seus interiores é interpretado como uma tentativa de "compensar o desaparecimento dos vestígios da vida privada na cidade grande - que é, paradoxalmente, o lócus do indivíduo burguês”, reunindo ali o longínquo e o distante, numa "última tentativa para não deixar se perder o rastro de seus dias sob a face da Terra" ${ }^{35}$ :

Sem descanso, tira molde de uma multidão de objetos; procura capas e estojos para chinelos e relógios de bolso, para termômetros e porta-ovos, para talheres e guarda-chuvas. Dá preferência a coberturas de veludo e de

\footnotetext{
${ }^{30}$ BENJAMIN, 2004, p. 101.

31 "Quem visitasse a velha senhora, na sua janela de sacada, alcatifada, guarnecida de uma pequena balaustrada e dando para o pátio, dificilmente poderia imaginá-la nas grandes viagens marítimas ou mesmo em excursões ao deserto, que de tempos em tempos fazia, através da agência de viagens "Stangens Reisen'”. In: BENJAMIN, 2004, p. 100.

32 BENJAMIN, 2004, p. 101.

33 BENJAMIN, 2004, p. 101.

${ }^{34}$ Ibid. p. 101.

35 BASSANI, Jaison José. Corpo, educação e reificação: Theodor W. Adorno e a crítica da cultura e da técnica. 2008. Tese de Doutorado. Universidade Federal de Santa Catarina, Centro de Ciências de Educação. Programa de Pós-graduação em Educação, Florianópolis, 2008, p. 95.
} 
pelúcia, que guardam a impressão de todo o contato. Para o estilo Makart do final do Segundo Império, a moradia se torna uma espécie de cápsula. Concebe-a como um estojo do ser humano e nela o acomoda com todos os seus pertences, preservando, assim, os seus vestígios, como a natureza preserva no granito uma fauna extinta. ${ }^{36}$

Ao lado do tema do fim da vida, encontramos também, como dito acima, o do sexo. Os aforismos "O despertar do sexo" e "Notícias de uma morte" representam, de maneira intensa, essa ambiguidade da natureza humana: o equilíbrio tenso, dinâmico, frágil entre existir e deixar de $\operatorname{ser}^{37}$, entre pulsão de vida, erótica, criadora, e pulsão de morte, também sedutora, mas destruidora. Essa caracterização pode ser encontrada em Freud ${ }^{38}$, para quem as pulsões de vida e de morte são dois lados de uma mesma moeda, existindo simultaneamente no indivíduo.

As primeiras experiências eróticas da criança que Benjamin havia sido estão magistralmente rememoradas no aforismo “A despensa". Nele, não vemos uma rígida separação entre o corpo e os objetos físicos a ele exteriores, postura que será exigida pelos dispositivos civilizadores em relação a esse comportamento mimético, de mistura e indeterminação do sujeito ${ }^{39}$. O erotismo presente nos fragmentos de memória narrado no aforismo reflete o caráter sensual dos elementos físicos ao redor da criança. Essa característica diz respeito à maneira peculiar da criança de relacionar-se não apenas com as guloseimas que ficam guardadas na despensa, mas com os objetos em geral, ou seja, percebemos que o pote de amêndoas ou de frutas cristalizadas é a extensão dos próprios

\footnotetext{
${ }^{36}$ BENJAMIN, 2010, p. 43-44.

37 No aforismo "Fragmento de uma teoria do criminoso", presente nas "Notas e Esboços" da Dialética do esclarecimento, Horkheimer e Adorno se referem de maneira emblemática a essa tensão: “A energia necessária para se destacar como um indivíduo do mundo ambiente e, ao mesmo tempo, para estabelecer uma ligação com ele, através das formas de comunicação autorizadas, e assim nele se afirmar estava corroída no criminoso. Ele representa uma tendência profundamente arraigada no ser vivo e cuja superação é um sinal de evolução: a tendência a perder-se em vez de impor-se ativamente no meio ambiente, a propensão a se largar, a regredir à natureza. Freud denominou-a pulsão de morte, Caillois le mimétisme”. In: HORKHEIMER; ADORNO, 1985, p. 259-260.

${ }^{38}$ Cf. Essa relação/oposição entre os instintos de vida e morte aparece em: FREUD, Sigmund. Além do princípio do prazer. In: . Obras completas volume 14. Tradução de Paulo César de Souza. São Paulo: Companhia das Letras, 2010.

39 "Para a civilização, a vida no estado natural puro, a vida animal e vegetativa, constituía o perigo absoluto. Um após o outro, os comportamentos mimético, mítico e metafísico foram considerados como eras superadas, de tal sorte que a idéia de recair neles estava associada ao pavor de que o eu revertesse à mera natureza, da qual havia se alienado com esforço indizível e que por isso mesmo infundia nele indizível terror. A lembrança viva dos tempos pretéritos [...] fora extirpada da consciência dos homens ao longo dos milênios com as penas mais terríveis". In: HORKHEIMER; ADORNO, 1985, p. 48.
} 
sentidos, visto que, ao tocá-lo, tocamos o próprio corpo, desfrutando de prazer. Isso porque, como dirá Horkheimer, o corpo inteiro é ainda, no caso da criança, um órgão mimético ${ }^{40}$ :

Na fresta deixada pela porta entreaberta do armário da despensa, minha mão penetrava tal qual um amante através da noite. Quando já se sentia ambientada naquela escuridão, ia apalpando o açúcar ou as amêndoas, as passas ou as frutas cristalizadas. E, do mesmo modo que o amante abraça sua amada antes de beijá-la, aquele tatear significava uma entrevista com as guloseimas antes que a boca saboreasse sua doçura. Com que lisonjas entregavam-se à minha mão o mel, os cachos de passas de Corinto e até o arroz! Com que paixão se fazia aquele encontro, uma vez que escapavam à colher! Agradecida e desenfreada, como a garota raptada de sua casa paterna, a compota de morango se entregava mesmo sem o acompanhamento do pãozinho e para ser saboreada ao ar livre, e até a manteiga respondia com ternura à ousadia de um pretendente que avançara até sua alcova de solteira. A mão, esse Don Juan juvenil, em pouco tempo, invadira todos os cantos e recantos, deixando atrás de si camadas e porções escorrendo a virgindade que, sem protestos, se renovava. ${ }^{41}$

Do mesmo modo que a passagem acima sugere, a relação com o tema da sexualidade também se encontra na fronteira entre a sinagoga e a rua — lugares "em que se misturam a profanação do dia santo e a cumplicidade da rua"42 — ou entre a casa e a cidade, enfim, entre interior e exterior, lugares de mediações em que o sujeito se descobre em todas as suas capacidades, e que revelariam os traços das primeiras experiências da dor, da morte e do sexo ${ }^{43}$.

Essas descobertas permitem a Benjamin vislumbrar um futuro e uma nova configuração do indivíduo em seus escritos. Infância berlinense é movida também, segundo nossa interpretação, pela imagem de uma esperança no tempo e no espaço que estão por vir, recuperados pela imaginação de uma criança na representação de um novo começo. O filósofo propõe uma abordagem paradigmática à modernidade, com base em outra leitura para a história coletiva, para a memória do passado. Por isso, é tão ousado na escrita, na forma de abordar essas temáticas. Infância berlinense é uma verdadeira experiência com a linguagem, uma experiência em um momento, aos olhos de Benjamin, fronteiriço (no tempo, não no espaço) da humanidade: no limiar entre um passado que já não existe mais, a não ser pelas lembranças, e um futuro que "ainda não" chegou.

\footnotetext{
${ }^{40}$ HORKHEIMER, M. Eclipse da razão. Tradução de Sebastião Uchoa Leite. São Paulo: Centauro, 2000.

${ }^{41}$ BENJAMIN, 2004, p. 87-88.

42 BENJAMIN, 2004, p. 122.

43 “A hipótese de Chaves (1999), de que a prostituta é a figura/imagem que representa a associação entre morte e sexo, parece pertinente para compreender o que na notícia da morte do primo distante narrada pelo pai teria traumatizado Benjamin. Sua dor, seu trauma, possivelmente guarda relação com o interdito paterno em relação à prostituição, com a velada ameaça de morte pela sífilis, pelas doenças do sexo". (MOMM, 2006, p. 82).
}

Dialektiké. Ano 2, v. 2, out 2015, p. 59-88 | Revista de Filosofia 
No texto sobre Moscou, reconhecemos que forma e conteúdo se alinham, pois na medida em que encontramos uma descrição da capital russa, o corpo do viajante é prolongado à própria descrição de Moscou na narrativa da cidade. E assim, simultaneamente, o corpo do homem e o corpus moscovita se encontram num esquema imagético incomum.

Ainda sobre essa representação da cidade e do corpo do viajante numa mesma imagem, pensamos que a ideia, em Diário de Moscou, era distanciar a capital russa de qualquer conceituação, apresentando "Moscou sob o ponto de vista que nela 'todo fato já é teoria' e, consequentemente fazendo, [abster-se] de qualquer abstração dedutiva..."44. Benjamin queria, a qualquer custo, fazer uma experiência tal com a linguagem que "a imagem [fosse] captada na escrita"45. Quando descreve o Kremlim, temos um maravilhamento acompanhando seu olhar — imagem traduzida em palavras — sobre o palácio:

Só posso compará-lo à impressão transmitida pelos edifícios da pequena cidade-modelo de Mônaco, um aglomerado habitacional privilegiado pela estreita proximidade dos governantes. Até as cores claras das fachadas, pintadas de branco ou amarelo-creme, são semelhantes. Mas, enquanto lá tudo é bem definido no jogo afinado de luz e sombra, aqui domina a claridade uniforme de um campo coberto de neve, que dá origem a um contraste mais sereno entre as cores. Mais tarde, quando escureceu gradualmente, o campo de neve parecia expandir-se mais e mais. Perto das janelas radiantes dos edifícios administrativos, as torres e cúpulas elevavamse em direção ao céu noturno: monumentos vencidos montando guarda nos portões dos vencedores. Feixes de luz irradiam dos faróis extremamente brilhantes dos carros atravessam, também aqui, a escuridão. Se brilho espanta os animais da cavalaria que têm aqui no Kremlin uma extensa área de adestramento. Pedestres buscam seu caminho, com dificuldade, por entre carros e cavalos assustados. Longas filas de trenós, usados na remoção de neve, cavaleiros isolados. Bandos silenciosos de corvos pousados na neve. Diante do portão do Kremlim, na luz ofuscante, ficam as sentinelas, com seus insolentes casacos de pele amarelo-ocre. Acima deles brilha a luz vermelha que regula o tráfego pelo portão. Como num prisma, todas as cores de Moscou convergem para este ponto, o centro do poder russo. ${ }^{46}$

O texto sobre a viagem a Moscou e a Berlim da infância, rememorada pelo adulto, alicerça-se em torno da noção de uma experiência sensorial, uma "análise imagética" 47 . As figuras comparativas entre a criança e o viajante podem ser colocadas no mesmo nexo interpretativo que a do colecionador - figura alegórica importante na sua análise da modernidade e suas

\footnotetext{
${ }^{44}$ MURICY apud BENJAMIN. In: MURICY, Kátia. Alegorias da dialética: imagem e pensamento em Walter Benjamin. Rio de Janeiro: Nau Editora, 2009, p. 22.

${ }^{45}$ Ibid, p. 23.

${ }^{46}$ BENJAMIN, 1980, p. 79-80.

${ }^{47}$ BUCK-MORSS, 2002, p. 53.

Dialektiké. Ano 2, v. 2, out 2015, p. 59-88 | Revista de Filosofia 
formas de percepção - posto que o autor também percorreu a capital russa em busca de brinquedos e livros infantis para sua própria coleção particular. A ideia de uma reunião idiossincrática de objetos figurada em coleção transforma as relações corporais que temos com esses elementos, expande-os para nossa própria alma, já que revelam muitos dos hábitos e dos modos de ser, em geral, de quem os coleciona. Essa figura alegórica está muito próxima tanto do viajante quanto da criança. A montagem e organização dos objetos e adereços que organizam o universo de ambos satisfaz uma necessidade de resguardo, uma tentativa de fundação de sentidos e significados idiossincráticos, fora do âmbito pragmático da realidade. A coleção suspende o tempo, institui relações casuais de ordem, tornando sensível o próprio toque, o olhar, ao instaurar continuamente uma atitude de surpresa com o próprio corpo. Isso se justifica porque o "verdadeiro método de tornar as coisas presentes é representá-las em nosso espaço. [...] Não somos nós que nos transportamos para dentro delas [as coisas], elas é que adentram a nossa vida"48. O colecionar reorganiza os espaços, recriando novas experiências com nossa condição de humanos. Esse mesmo ato funda a biografia de cada indivíduo de modo exclusivo.

Comparando ainda essa figura alegórica com nossa análise, percebemos que no aforismo "Filatelia", é possível reconhecer a associação entre o colecionador, a criança e o viajante:

\begin{abstract}
A criança olha para a distante Libéria através de binóculos de ópera assestados ao contrário: lá está ela, atrás de sua réstia de mar, com as suas palmeiras, tal como a mostram os selos. Com Vasco da Gama, a criança contorna à vela um triângulo, equilátero como a esperança e cujas cores se alteram com as mudanças atmosféricas. [...] A criança percorre, como Gulliver, países e povos dos seus selos. Aprende no sono a geografia e a história dos liliputianos, toda a ciência do pequeno povo com todos os seus números e nomes. Participa dos seus negócios, assiste às suas purpúreas assembleias populares, está presente no lançamento dos seus barquinhos e celebra o jubileu das suas cabeças coroadas, sentadas em tronos atrás de sebes. ${ }^{49}$
\end{abstract}

A criança é uma colecionadora na medida em que não estabelece as relações de causa, efeito e significados das coisas já dadas, pois seu corpo é uma perpétua novidade juntamente com tudo aquilo que a cerca. No mesmo sentido, o viajante, na visita a um lugar novo, sente que seu corpo, assim como a cidade que o cerca, é uma dimensão desconhecida.

\footnotetext{
${ }^{48}$ BENJAMIN, 2009, [H 2, 3].

${ }^{49}$ BENJAMIN, 2004, p. 58-59. 
Similar ao que acontece na Berlim revisitada da memória — do corpo —, Benjamin percorre a cidade de Moscou e também busca encontrar a si mesmo nessas coleções de caixinhas, brinquedos e livros infantis que tanto admira:

Havia alguns dias que, como me acontece muito, só prestava atenção em uma única coisa ao caminhar pelas ruas: desta vez, justamente nas caixas laqueadas. Um namoro curto e apaixonado. Quero comprar três - mas ainda não tenho certeza do que irei fazer com as duas que já adquiri. Neste dia, comprei a caixinha com as duas moças sentadas junto ao samovar. É muito bonita - embora não tenha aquele preto puro que é, em geral, o mais belo nelas. ${ }^{50}$

Caminhar pela cidade em busca de si mesmo é um ato típico das cidades urbanizadas. Funda um espaço de interioridade no espaço público, em que as fronteiras do corpo são atravessadas por lugares de encontro: "quem quiser saber o quanto estamos nos sentindo em casa nas vísceras, deve deixar a vertigem levá-lo pelas ruas [...]"51.

\section{O VIAJANTE E A CRIANÇA}

No filme Asas do desejo (Der Himmel über Berlin - O céu sobre Berlim), de Wim Wenders $^{52}$, podemos reconhecer uma afinidade eletiva entre a experiência de um anjoviajante, que acabou de "cair", ou seja, que deixou a condição de ser, que não possui a experiência errática do mundo, que não vivenciou a condição de mortal, para a de humano, e da criança que acabou de "nascer", enquanto metáforas da mais pura potência de ser. O anjoviajante, que percorre a cidade para apoiar a trajetória dos humanos na Terra, sente inveja deles, pois anseia sentir também as percepções do próprio corpo, no que ele tem de nocivo e prazeroso, em suma, as afetações que ele fornece. Em última instância, sentir o próprio, para o melhor ou para o pior, é saber, ter a nítida sensibilidade da corporalidade de estar vivo. As falas obedecem ao tempo de uma narração, de uma história que é contada, seguindo um tempo subjetivo, relacionado às memórias de quem narra, como as de um viajante e de uma criança:

Quando a criança era criança/Amoras caiam em suas mãos/E ainda é assim.../As nozes deixavam sua língua áspera, e ainda o fazem/Ao chegar ao

\footnotetext{
50 BENJAMIN, 1980, p. 92.

${ }^{51}$ BENJAMIN, 2009, p. 560 [P 2, 2].

52 Cf. Asas do desejo é um filme alemão de 1987 que narra a perambulação de dois anjos, Cassiel e Damiel, numa Berlim devastada pela $2^{\mathrm{a}}$ Guerra.
}

Dialektiké. Ano 2, v. 2, out 2015, p. 59-88 | Revista de Filosofia 
topo da montanha, queria outra mais alta./Em cada cidade, deseja outra cidade maior./E ainda o faz./Subia nas árvores para colher cerejas com grande alegria, como hoje/Ficava tímida diante de estranhos, e ainda fica./Aguardava a primeira neve e continua aguardando./Quando a criança era criança atirou uma lança de madeira contra uma árvore a qual tremula ali ainda hoje. ${ }^{53}$

Nas colinas, um velho lê "Odisséia" para um garoto que pára até de piscar./Uma cega, sentindo minha presença apalpa o relógio.(...)Eu gostaria de poder dizer "agora" a cada passo, cada rajada de vento./Não, não preciso ter um filho ou plantar uma árvore mas seria bom voltar0poi/ para casa após um longo dia para comer, como o gato Philip Marlowe./Ter febre, dedos pretos por causa do jornal./ Não vibrar apenas pelo espírito, mas por uma refeição, pelos contornos de uma nuca, de uma orelha./Pelo menos sentir como é tirar os sapatos debaixo da mesa./Torcer os dedos do pé descalço, $\operatorname{assim} .{ }^{54}$

O viajante é uma modalidade de narrador, de contador de histórias que conseguiria, junto com aquele de seu próprio país (o segundo tipo de narrador que Benjamin menciona ${ }^{55}$ ) tornar sua existência matéria de história, pois "[...] "quem viaja tem muito o que contar", diz o povo" 56 . O narrador-viajante estabelece uma relação artesanal com sua vida.

O anjo-viajante também é criança quando percorre a cidade durante o filme: "Por que eu sou eu, e não sou você? Quando começou o tempo e onde termina o espaço?" Quando o anjo Damiel se torna humano, seus sentidos corporais são conduzidos para as mesmas novidades que o corpo de uma criança: as sensações, percepções, sentimentos estão surgindo aos poucos. Tudo o que sente é novidade, uma descoberta. Por isso, parece existir no filme uma necessidade de contar a experiência de um lampejo (Aufblitzen), de algo que se descobriu ao longo do caminho e que precisa ser contado, narrado, em última instância, comunicado: a própria vida, sua biografia, uma existência que é única.

A Berlim narrada no longa-metragem também é uma cidade muito particular, assim como o é para Benjamin, pois é a Berlim do cineasta Wenders: conseguimos ter a mesma percepção que em Infância berlinense, ou seja, de que só é possível falar de uma cidade que tenha se tornado matéria da experiência, em outras palavras, lugar de interioridade, de uma “estética dos detalhes", matéria da vida.

\footnotetext{
${ }^{53}$ Poema escrito por Peter Handke, exclusivamente para o filme.

${ }^{54}$ Cf. WENDERS, 1987, 00h24min.

55 Cf: O viajante é similar ao cronista da história, pois a narra: “(...)Entre todas as formas épicas a crônica é aquele cuja inclusão na luz pura e incolor da história escrita é mais incontestável. E, no amplo espectro da crônica, todas as maneiras com que uma história pode ser narrada se estratificam como se fossem variações de uma mesma cor. O cronista é o narrador da história”. In: BENJAMIN, 2010, p. 209.
}

56 BENJAMIN, 2010, p. 198. 
Influenciado pelas teses Sobre o conceito de história de Benjamin, o diretor alemão, durante o filme, mostra a necessidade da história, da memória, das narrativas para a construção da identidade de um povo, de uma nação ${ }^{57}$. Próximo das ideias do filósofo, Wenders mostra como se constitui a esfera individual diante da coletiva e vice-versa. A metáfora sugerida pela imagem do corpo, das mãos na construção da história e da descoberta da cidade, é mostrada e reconhecida através das cenas em que visualizamos o poema-narrativa sendo escrito ao longo do filme. A proposital alternância entre preto e branco e colorido, no filme, também nos induz às mudanças de sensações que o anjo experimenta quando passa pelo processo de transformar-se em humano.

A Berlim narrada no filme representa o mundo, um desejo, a sensação de limiar da passagem dos tempos. Um símbolo de sobrevivência, em que diante de tantas atrocidades já vivenciadas durante a $2^{\text {a }}$ Guerra Mundial, o que restou foi "relacionar-se com as formas invisíveis do futuro e do passado".

\section{SENTIDOS DO CORPO E TÉCNICA}

[...] as palavras resistem, elas têm uma espessura, sua existência densa exige, para que elas sejam compreendidas, uma intervenção corporal, sob a forma de uma operação vocal: seja aquela da voz percebida, pronunciada e ouvida ou de uma voz inaudivel, de uma articulação interiorizada. [...] É nesse sentido que se diz, de maneira paradoxal, que se pensa sempre com o corpo: o discurso que alguém me faz sobre o mundo (qualquer que seja o aspecto do mundo de que ele me fala) constitui para mim um corpo-a-corpo com o mundo.

Paul Zumthor

O conceito de técnica é fundamental no pensamento de Benjamin para pensarmos as formas com as quais se caracteriza a relação do corpo com a natureza exterior. O filósofo alemão é bastante fatalista quando afirma a distância que o homem tomou da natureza com o desenvolvimento da ciência e seu aceleramento, fornecendo o próprio ritmo da vida na modernidade, e que foge do controle dos indivíduos. Por outro lado, todo avanço técnico mostra que é pela arte que conseguimos adquirir uma relação de aprendizado com o mundo.

As ameaças produzidas pela técnica e pelo desenvolvimento tecnológico sugerem que o caminho para desmistificar essa relação catastrófica com a natureza se qualifica pelo

${ }^{57}$ WENDERS, Wim. A lógica das imagens. Trad. Maria Alexandra A. Lopes. Lisboa: Edições 70, 1990, p. 105106. 
bom uso desses aparatos produzidos pelo homem. Consequentemente, a noção de corpo é ressignificada. A ideia de uma natureza humana está muito latente nas reflexões de Benjamin sobre a ciência e a técnica:

\begin{abstract}
A natureza se apresenta sob vários aspectos numa mesma época: ela pode ser tanto sinônimo da vida, quanto da morte, ela pode significar algo como "paisagem" e pode ser simplesmente o espaço físico em que as coisas acontecem. (...) Este último aspecto é importante no que diz respeito ao resgate do corpo e dos sentidos em Benjamin, ou seja, da natureza humana. A partir dessa acepção mais ampla da natureza como mundo físico e sua recepção pelos sentidos, podemos falar tanto da relação cotidiana do ser humano com seu ambiente, quanto o estudo desse ambiente por parte das ciências exatas, também chamada de "ciências naturais". Essa relação antropológica entre o homem e seu mundo é marcada por opostos, pela proximidade e a distância, pela concentração e a dispersão, pelo estático e o dinâmico, ou seja, por forças antagônicas que Benjamin considera como decisivos para a percepção e a representação desse mundo, e assim, para todo tipo de reflexão estética. ${ }^{58}$
\end{abstract}

No que diz respeito às modalidades artísticas ressaltadas nos dois ensaios analisados, o cinema e o teatro são as que Benjamin usufruiu intensamente em sua viagem a Moscou. Interessante notar, contudo, que sua análise é bastante intuitiva quando se debruça sobre os filmes e as peças na metrópole moscovita, já que desconhecia o idioma russo. Para tal crítica, ele se utilizava de traduções e explicações de seus colegas e amigos que o acompanhavam em tais episódios.

Em A obra de arte na época de sua reprodutibilidade técnica ${ }^{59}$, a categoria de jogo é explorada a partir dos “vários sentidos que esse termo tem em alemão: 'jogo', 'brincadeira', 'execução de uma música', 'interpretação ou representação teatral, cinematográfica de um personagem', 'ação livre, sem fins determinados [...]"”60, de modo que o elemento dialético que envolve a natureza na relação do sujeito histórico com as novas formas de percepção realizadas pelo corpo exerce aqui um papel relevante. A maneira do sujeito contemporâneo se relacionar com as modalidades recentes de arte e com a própria natureza, revela e coloca no centro o jogo como item que traduziria sua necessidade de dominação frente aquilo que o circunda.

\footnotetext{
58 OTTE, Georg. Natureza e história em Walter Benjamin. Revista Literatura e autoritarismo - dossiê Walter Benjamin e a literatura brasileira. Dossiê no 5. Disponível em: http://w3.ufsm.br/grpesqla/revista/ dossie05/art_08.php. Acesso em: 09 jul. 2013.

${ }^{59}$ BENJAMIN, Walter. A obra de arte na época de sua reprodutibilidade técnica. Porto Alegre: Zouk, 2012.

${ }^{60}$ Cf. Nota do tradutor Francisco de Ambrosis Pinheiro Machado. In: BENJAMIN, 2012, p. 44-45.
} 
O jogo está intensamente presente nas reflexões de Benjamin em seu Diário de Moscou, especialmente se o compreendermos como um elemento de tensão nas formas de percepção a que o corpo está sujeito, quando pensamos na dialética presente entre sua relação com o que há de novo e o que é familiar, entre o que há para descobrir e o que se torna elemento misterioso, entre o que é tempo "experienciado" e o espaço já formado, e ainda na relação entre espaço e tempo.

A categoria de jogo torna-se mediadora da relação que a humanidade adquiriu com a natureza, provocada pelo distanciamento e separação — necessária — entre o sujeito e aquilo que lhe era exterior, convertido em outro em relação a ele ${ }^{61}$. Essa mediação permite pensar a nova relação que os sentidos do corpo experimentam com o tempo e com o espaço categorias essenciais para nossa análise. Por isso, acreditamos que as figuras que melhor traduzem o vínculo, isto é, o jogo entre espaço e tempo, são a criança e o viajante. Para a primeira, o tempo é medido pelos espaços da casa e da rua: pelos monumentos e espaços públicos, como o Tiergarten, o panorama imperial e a Coluna da Vitória; pela dimensão e pelos elementos da sala de aula na escola, como o relógio e o pátio; pela brincadeira infantil, na caça às borboletas ou nos esconderijos; pelos prazeres e desejos, como a descoberta do sexo; pela dor, seja pela notícia de uma morte seja por febre ou doença; pelo sabor da comida, como a maçã quente saída do forno, etc.

Benjamin está interessado, na verdade, nas recentes formas de percepção, que no que diz respeito à discussão das transformações da subjetividade apoiadas pela crescente socialização dos meios técnicos de expressão cultural, como o jornal e o cinema. Para ele, não haveria uma hierarquização da cultura em seus usos, posto que, por exemplo, "a competência literária não se funda mais na formação especializada, mas na politécnica, e, assim, torna-se bem comum"62.

Em Diário de Moscou é possível perceber sua exaltação pelo teatro e pelo cinema. No texto sobre a reprodutibilidade técnica das obras de arte - escrito posteriormente ao Diário, - Benjamin sistematiza essa exaltação, ressaltando a dimensão técnica, o valor do trabalho e a educação de uma subjetividade recente, unidas numa mesma estrutura:

${ }^{61}$ Cf. "A origem da segunda técnica deve ser buscada lá onde o homem, pela primeira vez e com astúcia inconsciente, começou a tomar distância da natureza. Encontra-se, em outras palavras, no jogo". In: BENJAMIN, 2012, p. 43.

${ }^{62}$ BENJAMIN, 2012, p. 81.

Dialektiké. Ano 2, v. 2, out 2015, p. 59-88 | Revista de Filosofia 
A diferença entre autor e público está a ponto de perder seu caráter essencial. Ela se torna funcional, variando em cada caso. O leitor está sempre pronto para se tornar um escritor. [...] Tudo isso pode ser transposto sem mais para o cinema, onde os deslocamentos, que na literatura demandam séculos, realizaram-se no decorrer de uma década. Pois, na práxis do cinema sobretudo no cinema russo - esse deslocamento em parte já foi realizado. Alguns dos atores que se encontram no cinema russo não são atores no nosso sentido, mas pessoas que se representam - e isso, em primeira linha, no seu processo de trabalho. ${ }^{63}$

Em "Panorama imperial" ${ }^{64}$, aforismo de Infância berlinense, encontramos uma narração sobre essa maquinaria histórica, representativa de um novo tipo de aparato que mudaria, substancialmente, a maneira como nos relacionamos com a tecnologia. Isso representa a modificação dos nossos sentidos, percepções, sensações, em suma, da mediação entre o corpo e a aparelhagem técnica. A imagem do panorama - imagem de um mosaico - nos fornece a sensação de uma diminuição das distâncias de categorias como dentro e fora, interior e exterior, casa e cidade.

Temos a ilusão sensorial, graças à ilusão do aparato técnico, de uma imersão na cidade, como podemos perceber no trecho a seguir:

O interesse pelo panorama consiste em ver a verdadeira cidade - a cidade dentro da casa. O que se encontra na casa sem janelas é o verdadeiro. Aliás, também a passagem é uma casa sem janelas. As janelas que a olham de cima são os camarotes de onde se pode olhar para o seu interior, mas não para o seu exterior. ( $\mathrm{O}$ verdadeiro não possui janelas; o verdadeiro não dirige em lugar algum seu olhar para o universo). ${ }^{65}$

A cultura material em Moscou é também pensada por Benjamin no ensaio intitulado "Brinquedos russos". Escrito em 1930, anos após sua estada em Moscou, nele o autor ressalta a importância do processo de fabricação do brinquedo infantil. As técnicas primitivas de confecção de tais produtos constituem seu valor "lúdico" na medida em que a forma do objeto concentra o espírito da produção do material, uma vez que a criança, por meio da sua imaginação, tem a capacidade de reconstruir cada passo da técnica utilizada na fabricação do brinquedo que tem em mãos, obtendo o resultado final da construção artesanal — matéria de

\footnotetext{
${ }^{63}$ Ibid, p. 79-81.

${ }^{64}$ Cf. "No original Kaiserpanorama: método de projeção de imagens, antecessor do cinema, constituído por um grande ciclorama circular em que eram projectadas imagens de paisagens. $\mathrm{O}$ espectador, sentado no centro do círculo, tinha a ilusão de ver de cima, através de um sistema de estereoscópios individuais, o que passava diante de olhos". In: BENJAMIN, 2004, p. 18, nota do tradutor.
}

${ }^{65}$ BENJAMIN, 2009, [Q 2a 7]. 
gênio $^{66}$, marca de sua individualidade, do traço exclusivo, de uma personalidade criadora que não se equivale a nenhuma outra.

A técnica artesanal dos brinquedos russos é bastante extensa em quantidade e variação: "a primitiva riqueza de formas do povo baixo, dos camponeses e artesãos, constitui até os dias de hoje uma base segura para o desenvolvimento do brinquedo infantil" ${ }^{\text {"67. Diante }}$ do exposto, é possível formular a seguinte reflexão: a de que existe uma relação de continuidade entre o corpo e os objetos materiais. A expressão tátil do marceneiro está presente nessa cultura corporal, podendo ser encontrada em diversos museus da capital russa.

Benjamin levanta ainda outras reflexões sobre as novas formas de percepção, como as que modificam os aparatos cognitivos humanos na modernidade e que inauguram um tipo de experiência que o sujeito divide com a cultura material presente em sua vida.

\section{SENTIDOS DO CORPO E INCONSCIENTE ÓPTICO ${ }^{68}$}

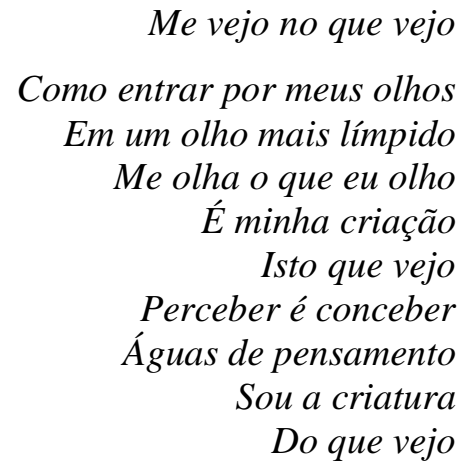

Octavio Paz, versão de Haroldo de Campos

Pensar numa corporalidade no pensamento de Benjamin nos remete à categoria de inconsciente ótico, no que diz respeito às diferentes configurações históricas nas quais o sujeito obtém suas percepções e sensações corporais no período moderno, similarmente à "descoberta" do inconsciente pulsional definido por Freud. As mudanças ocorridas na natureza humana definem uma nova ordem revelando, por sua vez, como o indivíduo adquire

\footnotetext{
${ }^{66}$ BENJAMIN, Walter. Brinquedos russos. In: Reflexões sobre a infância, o brinquedo e a educação. Trad. Marcus Vinicius Mazzari. São Paulo: Duas Cidades; Ed. 34, 2009, p. 127.

${ }^{67}$ Ibid, p. 127.

${ }^{68}$ Cf. Termo cunhado por Walter Benjamin no ensaio: BENJAMIN, Walter. Pequena história da fotografia. In: . Magia e Técnica, Arte e Política. Tradução de Sergio Paulo Rouanet. São Paulo: Brasiliense, 2010. Posteriormente, em A obra de arte na época de sua reprodutibilidade técnica, o filósofo destacará a importância do inconsciente óptico nas novas formas de percepção.
} 
suas experiências com o corpo. No ensaio sobre a obra de arte, o filósofo admite muitas aproximações entre o pulsional, determinado pela psicanálise, e o óptico. O inconsciente ótico seria a extensão do olho humano proporcionado pela fotografia e pelo cinema, pela sua capacidade de ampliar nossos sentidos, mais ainda: esses aparatos técnicos abririam "portas da percepção" impenetráveis ao "olho" humano, conseguindo chegar a um nível de detalhamento da realidade que o indivíduo não alcança. $\mathrm{O}$ inconsciente ótico muda nossa maneira de enxergar a realidade, nossa relação com os objetos no mundo, momento em que a fronteira entre sonho e realidade se dissipa e os sonhos coletivos tornam-se fatos no mundo ${ }^{69}$. Ele conseguiria libertar a massa coletiva de suas repressões sociais por meio da catarse alcançada pelo cinema ${ }^{70}$. O cinema e a fotografia alcançariam camadas da realidade que nosso corpo não atinge:

Se é comum se dar conta, mesmo que em grandes traços, do andar das pessoas, não se sabe certamente nada sobre sua posição na fração de segundo em que são um passo. Se nos é familiar, ainda que grosso modo, o ato de pegar o isqueiro e a colher, nada sabemos, todavia, do que se passa propriamente entre a mão e o metal, menos ainda como isso se altera de acordo com as diferentes disposições em que nos encontramos. Aqui, a câmara intervém com seus recursos auxiliares, se descer e subir, seu interromper e isolar, seu dilatar e acelerar a sequência, seu ampliar e diminuir. Por meio dela tomamos, pela primeira vez, conhecimento do inconsciente óptico, tal como tomamos conhecimento do inconsciente pulsional pela psicanálise. ${ }^{71}$

Infância berlinense e Diário de Moscou são ensaios que se assemelham a imagens congeladas no tempo. Não obstante suas características fragmentadas e aforismos que não possuem uma necessária interdependência uns dos outros, mesmo assim, ou justamente por conta disso, mediam uma compreensão que não é apenas idiossincrática do autor, mas também coletiva, como procuramos evidenciar ao longo do artigo. Contudo, para além dessa esfera comum, encontramos nesses ensaios uma analogia com a fotografia, mais especificamente, com a ideia de um inconsciente ótico, que representa a corporalidade como forma de escrita, revelando o

\footnotetext{
${ }^{69}$ BENJAMIN, 2012, p. 101.

${ }^{70} \mathrm{CF}$. "Levando-se em conta as perigosas tensões que a tecnicização, com suas consequências, engendrou nas grandes massas - tensões que, em estágios críticos, assumem um caráter psicótico -, então, reconhecer-se-á que essa mesma tecnicização criou, contra tais psicoses das massas, a possibilidade de uma vacina psíquica por meio de certos filmes, nos quais o desenvolvimento forçado de fantasias sádicas ou delírios masoquistas pode impedir o amadurecimento natural e perigoso destes nas massas. A risada coletiva representa a erupção prematura e saudável de tal tipo de psicose de massa”. In: BENJAMIN, 2012, p. 103.

${ }^{71}$ Ibid, p. 99.
} 
"aspecto fisionômico" com que Benjamin reflete sobre sua infância e sobre sua viagem à Moscou.

Nesse horizonte, podemos perceber as características de uma "fotografia da vida fragmentada" quando o filósofo promove uma sequência de imagens nas menores coisas que rememora. A relação entre técnica e magia também é um fator que se destaca, pois as descrições de "O Telefone" e "Panorama Imperial", aliadas às mudanças sociais do início do século XX por ele analisadas, foram muito marcadas por esse "entre lugares": ou seja, entre a técnica, a ciência e a experiência de cunho mágico, sobrenatural.

Benjamin quer realizar, com esse agrupamento de argumentos, aforismos e fragmentos soltos em conjunto, uma cadeia de imagens, semelhante às que são produzidas e depois passam pelo processo de montagem na realização de um filme. Conforme já dissemos, ele quer promover um estranhamento com a forma de escrita construída a partir de pequenos pensamentos, quer nos tirar do lugar comum, "para o olhar politicamente educado [n]o espaço em que toda intimidade cede lugar à iluminação dos pormenores"72.

Analogamente aos fotógrafos que capturam uma imagem do mundo físico, com técnicas de redução, etc., o berlinense, pelas técnicas da própria linguagem e da transposição da imagem na escrita, promove uma verdadeira "miniaturização da realidade", blocos de pensamento na linguagem aforismática.

A noção de inconsciente ótico em Benjamin nos condiciona a pensar que Infância e Diário são textos que revelam uma manifestação de algo que já se encontrava na memória do narrador, daquele que está evocando reminiscências, resultado de uma experiência já vivida e de quadros históricos demarcados. Outra característica importante diz respeito também àquela espontaneidade com que Proust revive as situações de seu passado: a recepção do espectador, a entrega ${ }^{73}$ com que contempla determinado objeto, e que permite a ele escavar as recordações contidas no universo obscuro de sua memória.

Em cada fragmento analisado, o inconsciente ótico revela-nos um retrato: um espelho de si mesmo e do coletivo histórico. Sobretudo, um retrato que é construído, que não está dado pronta e previamente, que é condicionado pelas experiências com o próprio corpo, por suas afetações.

\footnotetext{
72 BENJAMIN, 2010, p. 102.

${ }^{73}$ No contexto do cinema, Benjamin chama essa "entrega" de "recepção na distração [aquilo] que se observa com intensidade cada vez maior em todos os domínios da arte e que é sintoma de uma profunda mudança da apercepção, tem no cinema seu instrumento de exercício próprio”. In: BENJAMIN, 2012, p. 115.
} 
Os dois ensaios rementem à ideia de representação. Ao mesmo tempo em que tratam de uma autobiografia, de um diário, enfim, de lugares de confissões, são também diagnósticos de um tempo, de uma sociedade. Há, dessa forma, um campo de forças em que se coadunam o próprio Benjamin enquanto indivíduo, na construção de sua biografia, e, ao mesmo tempo, um eu que representa uma multidão, o espaço do coletivo, de uma identidade em comum com outros.

O tema da mímesis e da racionalidade é relevante para Benjamin. E embora não nos deteremos muito sobre essa questão, é importante dizer que a mímesis — palavra de origem grega traduzida, em geral, por imitação ou representação - é uma capacidade humana que sempre foi depreciada ao longo da história do pensamento. Ela ganhou território com Aristóteles - que acreditava na função catártica que a imitação e representação da vida no teatro poderiam fornecer aos espectadores, possibilitando um meio de purgação positiva - e posteriormente, na contemporaneidade, com Benjamin, que a define exemplarmente em sua teoria da linguagem humana.

Ele propõe uma teoria da mímesis que identifica um potencial criativo muito além da simples capacidade de imitação, significado restrito pelo qual geralmente essa palavra é compreendida e interpretada. Por isso que, em Infância berlinense, a temática da mímesis percorre o texto como um todo, uma vez que a criança é quem melhor representa "a capacidade de criar e reproduzir semelhanças" $" 74$.

Importante destacar que a mímesis é definida como "a capacidade suprema de produzir semelhanças" enquanto que "[...] a brincadeira infantil constitui a escola dessa faculdade. Os jogos infantis são impregnados de comportamentos miméticos, que não se limitam de modo algum à imitação de pessoas"75. No aforismo "A meia", encontramos uma referência interessante para pensar sobre esse amplo tema e como ele se desdobra na questão do inconsciente, dos arquétipos e da noção de imagem: a noção de uma "aventura", ênfase na imaginação, a transmutação da meia em "bolsa", a "revelação" do jogo, do sonho, a relação entre forma e conteúdo. No texto "Imagem de Proust", o autor comenta essa capacidade de produção de semelhanças — que tem na criança seu representante máximo — à luz da obra do escritor francês:

\footnotetext{
${ }^{74}$ BENJAMIN, 2010, p. 108.

${ }^{75} \mathrm{Id}$, p. 108. 
A semelhança entre dois seres, a que estamos habituados e com que nos confrontamos em estado de vigília, é apenas um reflexo impreciso da semelhança mais profunda que reina no mundo dos sonhos, em que os acontecimentos não são nunca idênticos, mas semelhantes, impenetravelmente semelhantes entre si. As crianças conhecem um indício desse mundo, a meia, que tem a estrutura do mundo dos sonhos, quando está enrolada, na gaveta de roupas, e é ao mesmo tempo "bolsa" e "conteúdo". E, assim como as crianças não se cansam de transformar, com um só gesto, a bolsa e o que está dentro dela, numa terceira coisa - a meia -, assim também Proust não se cansava de esvaziar com um só gesto o manequim, o Eu, para evocar sempre de novo o terceiro elemento: a imagem, que saciava sua curiosidade ou sua nostalgia. ${ }^{76}$

Contudo, alguns aspectos da mímesis encontradas em Benjamin poderiam ser estendidos para um conceito ligado à categoria psicanalítica de inconsciente, mobilizada por ele para marcar as mudanças no aparato cognitivo humano, com as diferentes técnicas artísticas produzidas no século XX.

Aos cinco sentidos do corpo infantil, elementos-chave para a aquisição de conhecimento por parte da criança, poderíamos acrescentar, a partir das assertivas de Benjamin, mais um. Em Infância berlinense o autor parece "descobrir" outro sentido a partir de suas descrições da vida material e subjetiva da burguesia, das brincadeiras e dos jogos, enfim, das relações sociais da época. Esse "outro" sentido seria o da "telepatia".

Essa telepatia que parece fazer parte da narrativa de Infância berlinense diz respeito aos indícios que estão presentes no próprio texto. Longe de qualquer dom paranormal, essa "telepatia" diz respeito à capacidade do autor de ler, nas entrelinhas de uma história individual, os indícios de uma história coletiva, uma verdadeira correspondência entre as coisas, ou o dom de reconhecer e produzir semelhanças. O recurso à magia, como um momento anterior ao conhecimento científico, produziria a similitude entre as coisas e a comunicação entre elas. Freud, de acordo com a interpretação de Rouanet, descarta qualquer ideia de profecia, mas crê que haveria uma transmissão telepática de inconsciente a inconsciente:

[Freud] recorre a uma hipótese filogenética, que postula, na origem, uma forma de comunicação anterior a qualquer linguagem. /Poderíamos completar o pensamento de Benjamin, que nesse tema é bastante elíptico, reformulando, segundo suas categorias a tese de Freud. Seria possível, então, dizer que nesse estágio primitivo os indivíduos conseguiam captar as correspondências objetivas existentes na natureza e entre a natureza e o homem, e através dessa percepção, comum a todos, comunicavam-se entre

${ }^{76} \mathrm{Id}$, p. $39-40$.

Dialektiké. Ano 2, v. 2, out 2015, p. 59-88 | Revista de Filosofia 
si, sem necessidade da linguagem. As coisas se assemelham a outras coisas, o homem se torna semelhante às coisas, e os diversos membros de uma comunidade, capazes de perceber essas semelhanças e de produzi-las, são semelhantes entre si. / A telepatia se fundaria, em última instância, nessa capacidade mimética de perceber semelhanças e de se tornar semelhante. ${ }^{77}$

É fácil identificar em alguns aforismos de Infância as analogias ou telepatias que o autor parece encontrar entre seres animados e inanimados, ou seja, a prova do reconhecimento das semelhanças.

Podemos perceber nos aforismos "Caça às Borboletas", "Mummerehlen" e "Krumme Strasse”, por exemplo, essas símiles:

Caça às Borboletas. Começava a impor-se entre nós a velha lei dos caçadores: quanto mais eu me confundia com o animal em todas as minhas fibras, quanto mais eu me tornava borboleta no meu íntimo, tanto mais aquela borboleta se tornava humana em tudo o que fazia, até que, finalmente, era como se a sua captura fosse o único preço que me permitia recuperar a minha condição humana.

Mummerehlen. Em boa hora aprendi a me disfarçar nas palavras, que de fato, eram nuvens. $\mathrm{O}$ dom de reconhecer semelhanças não é mais do que uma fraca reminiscência da primitiva necessidade de nos tornarmos semelhantes e nos comportarmos de modo correspondente. As palavras exerciam sobre mim esse poder. Não aquelas que me tornavam igual às crianças exemplares, mas as que me aproximavam de casas, móveis, peças de roupas. Eu desfigurava-me pela semelhança com tudo o que existia à minha volta. Como um molusco na sua concha vazia. Levo-a ao ouvido, e que ouço? Não ouço o fragor de artilharia nem a música de baile de Offenbach, nem sequer os cascos dos cavalos na calçada ou as fanfarras da guarda na parada. Não, o que eu ouço é o ruído breve da antracite quando cai do recipiente de folha no fogo de ferro fundido, é o estalo seco que acompanha o acender da chama na camisa do candeeiro a gás, é o tinir da chaminé no aro de latão da lanterna, quando um carro passa na rua. E há outros ruídos, como o chocalhar das chaves no cesto, as campainhas das portas da frente e das traseiras; e também uma canção infantil.

Krumme Strasse: O instinto adivinha aquilo que mais insistentemente se irá revelar em nós, e funde-se com isso. ${ }^{78}$

Em conversa com Scholem, o filósofo transcreve essas aptidões extrassensíveis à categoria de "intuição", que ele acreditava manifestar-se na sensibilidade, ou seja, em nossa capacidade perceptiva, uma vez que tudo que se apresenta como pressentimento - o objeto que o suscita — manifesta-se, em última instância, no corpo.

\footnotetext{
${ }^{77}$ ROUANET, 2008, p. 141.

${ }^{78}$ BENJAMIN, 2004, p. 81, 106-107.

Dialektiké. Ano 2, v. 2, out 2015, p. 59-88 | Revista de Filosofia
} 
No hotel em Biel, onde pernoitamos, tivemos uma conversa sobre intuição. Anotei a definição que Benjamin apresentou para discussão: "O objeto da intuição é a necessidade de um conteúdo anunciar-se nos sentidos como puro para tornar-se perceptível. A percepção dessa necessidade se chama intuição. ${ }^{79}$

Benjamin levanta uma reflexão muito interessante, vinculada à de telepatia e intuição, em relação ao jogo, particularmente no ensaio "Sobre alguns temas em Baudelaire" e no livro Passagens. Ele parece querer situar suas preocupações sempre a partir do horizonte de uma percepção - podemos dizer - mais "etérea".

De alguma maneira, é pertinente pensarmos que existe uma categoria "a mais" além dos sentidos do corpo, muito presente, como a audição, o tato, a visão, já que o jogo está tomado por uma esfera fantasmagórica, enigmática, envolvendo elementos de cunho misterioso entre o jogador e o jogo em si:

O jogo, como qualquer outra paixão, dá a conhecer seu rosto como a faísca que salta, no âmbito do corpo, de um centro a outro, mobilizando ora este, ora aquele órgão, e reunindo e confinando nele a existência inteira. Este é o prazer concedido à mão direita até que a bolinha caia em seu compartimento. [...]. Este prazo é anunciado pelo instante, unicamente reservado ao ouvido, em que a bola penetra o redemoinho e o jogador fica à escuta de como a fortuna afina seus contrabaixos. No jogo, que se dirige a todos os sentidos, sem excluir o sentido atávico da clarividência, chega também a vez dos olhos. Todos os números lhes dão piscadelas. Como, porém, os olhos desaprenderam a linguagem dos gestos, no que ela tem de mais decisivo, na maioria das vezes conduzem ao erro os que neles confiam. ${ }^{80}$

O jogo está situado em uma relação com o tempo não cronológico e linear. Contudo, distante do horizonte do tempo da experiência, o jogo é uma categoria subjetiva em Benjamin, em que fica estabelecido uma proximidade e um distanciamento com o objeto, provocando uma ruptura das relações existentes entre sujeito e matéria de conhecimento. A ideia de "tempo infernal" é estabelecida, uma vez que "o tempo é o tecido no qual as fantasmagorias do jogo são urdidas" ${ }^{\prime 1}$.

Diante dessas questões relacionadas à intuição, ao jogo e a categorias extrassensíveis, esse conjunto de referências em que conduzimos nosso conhecimento sobre o corpo nos possibilita integrar outras instâncias da vida individual e coletiva, articulando-as a uma noção

\footnotetext{
${ }^{79}$ SCHOLEM, 2008, p. 91.

${ }^{80}$ BENJAMIN, 2009, p. 264-265.

${ }^{81}$ BENJAMIN, 2009, p. 130 (Nota de rodapé).
} 
importante de subjetividade que coloca o corpo no centro dessa formação pelas figuras emblemáticas da criança e do viajante.

\section{REFERÊNCIAS}

BASSANI, Jaison José. Corpo, educação e reificação: Theodor W. Adorno e a crítica da cultura e da técnica. 2008. Tese de Doutorado. Universidade Federal de Santa Catarina, Centro de Ciências de Educação. Programa de Pós-graduação em Educação, Florianópolis, 200

BENJAMIN, Walter. A obra de arte na época de sua reprodutibilidade técnica. Porto Alegre: Zouk, 2012.

Imagens de pensamento. Trad. João Barrento. Lisboa: Assírio \& Alvim, 2004.

Magia e técnica, arte e política. Trad. Sergio Paulo Rouanet. São Paulo: Brasiliense, 2010.

Reflexões sobre a infância, o brinquedo e a educação. Trad. Marcus Vinicius Mazzari. São Paulo: Duas Cidades; Ed. 34, 2009.

BRETON, David Le. Antropologia do corpo e modernidade. Tradução de Fábio dos Santos Creder Lopes. Petrópolis: Vozes, 2011.

BUCK-MORSS, Susan. Dialética do olhar: Walter Benjamin e o projeto das passagens. Trad. Ana Luiza Andrade. Belo Horizonte: Editora UFMG, 2002.

COSTA, Jurandir F. Notas sobre a cultura somática. In:

O vestígio e a aura: corpo e consumismo na moral do espetáculo. Rio de Janeiro: Garamond, 2005.

FREUD, Sigmund. Além do princípio do prazer. In: Obras completas volume 14. Trad. Paulo César de Souza. São Paulo: Companhia das Letras, 2010.

HORKHEIMER, M.; ADORNO, Theodor W. Dialética do esclarecimento: fragmentos filosóficos. Trad. Guido de Almeida. Rio de Janeiro: Jorge Zahar, 1985.

HORKHEIMER, M. Eclipse da razão. Trad. Sebastião Uchoa Leite. São Paulo: Centauro, 2000

MOMM, Caroline M. Entre memória e história: estudos sobre a infância em Walter Benjamin. 2006. 116 f. Dissertação (Mestrado) - Universidade Federal de Santa Catarina, Centro de Ciências da Educação. Programa de Pós-Graduação em Educação, Florianópolis, 2006.

MURICY, Kátia. Alegorias da dialética: imagem e pensamento em Walter Benjamin. Rio de Janeiro: Nau Editora, 2009. 
SCHOLEM, Gershom. Walter Benjamin: a história de uma amizade. Tradução de Geraldo Gerson de Souza et al. São Paulo: Perspectiva, 2008.

OTTE, Georg. Natureza e história em Walter Benjamin. Revista Literatura e autoritarismo - dossiê Walter Benjamin e a literatura brasileira. Dossiê $\mathrm{n}^{\mathrm{o}}$ 5. Disponível em: http://w3.ufsm.br/grpesqla/revista/dossie05/art_08.php. Acesso em: 09 jul. 2013.

PROUST, Marcel. A prisioneira. Trad. de Manuel Bandeira. São Paulo: Globo, 2011.

ROUANET, Sergio Paulo. Édipo e o Anjo: itinerários freudianos em Walter Benjamin. Rio de Janeiro: Tempo Brasileiro, 2008.

SELIGMANN-SILVA, M. Leituras de Walter Benjamin. São Paulo: Annablume, 1999.

WENDERS, Wim. A lógica das imagens. Trad. Maria Alexandra A. Lopes. Lisboa: Edições 70, 1990.

ZUMTHOR, Paul. Performance, recepção, leitura. Trad. Jerusa Pires Ferreira e Suely Fenerich. São Paulo: Cosac Naify, 2007. 